Intersections

Canadian Journal of Music

Revue canadienne de musique
Intersections

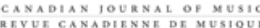

\title{
The Gregorian Institute of Canada: Traditions in Western Plainchant
}

\section{William Renwick}

Volume 29, numéro 1, 2009

URI : https://id.erudit.org/iderudit/039113ar

DOI : https://doi.org/10.7202/039113ar

Aller au sommaire du numéro

Éditeur(s)

Canadian University Music Society / Société de musique des universités

canadiennes

ISSN

1911-0146 (imprimé)

1918-512X (numérique)

Découvrir la revue

Citer cette note

Renwick, W. (2009). The Gregorian Institute of Canada: Traditions in Western Plainchant. Intersections, 29(1), 105-106. https://doi.org/10.7202/039113ar

Tous droits réservés (C) Canadian University Music Society / Société de musique des universités canadiennes, 2009
Ce document est protégé par la loi sur le droit d'auteur. L’utilisation des services d'Érudit (y compris la reproduction) est assujettie à sa politique d'utilisation que vous pouvez consulter en ligne.

https://apropos.erudit.org/fr/usagers/politique-dutilisation/ 


\title{
THE GREGORIAN INSTITUTE OF CANADA: TRADITIONS IN WESTERN PLAINCHANT
}

\author{
William Renwick
}

Since its inception in 2005, the Gregorian Institute of Canada, affiliated with the School of the Arts, McMaster University, has sought to develop a community of scholars and performers from across Canada to share with and engage each other in the research and practice of plainchant in all its richness and variety.

In 13-19 August 2009, "Traditions in Western Plainchant" brought together for the first time in Canada an impressive series of lectures and an equally spectacular program of workshops. In addition to our plenary speaker, Joseph Dyer, twenty other scholars from Canada, the United States, Great Britain, and France presented the results of their current research and/or performing practices.

The featured artist, Juan Carlos Asensio Palacios (Salamanca, Spain), presented in English and French practical introductions to the music of the proper of the mass, and to the chant in the early Spanish church.

Hamilton Schola Cantorum performed the opening concert, which ranged from simple psalmody through elaborate responsories, and also included a variety of polyphonic variations, including fauxbourdon, organum, and alternatim. Montreal's Schola Saint Grégoire, on this occasion directed by Juan Carlos Asensio Palacios, performed a concert of chant from all the principle Western traditions: Spanish, Ambrosian, Old Roman, Beneventan, and Sarum. By hearing in some instances the same chant in its various dialects, the audience was able to appreciate the subtle differences of style that mark theses several traditions. Stillman Matheson complemented the performance by playing selected regional repertoire on the organ.

In cooperation with Library and Archives Canada a display was mounted of significant chant publications from the French colonial period. This exhibit will be made available online in the coming months.

Paper sessions covered the topics of chant transmission, neumes and orality, and post-Tridentine chant, as well as a variety of practical sessions on performance practice and the liturgical reforms of the past century. In addition we were pleased to have an impressive group of papers from emerging scholars in the Becket Project (University of Toronto), who shared the results of their detailed analysis of key features of manuscripts that include the Office of St. Thomas of Canterbury.

In the wake of the Solesmes reforms, the seventeenth century has largely been dismissed as an age of decline in chant, but both Barbara Swanson and Joshua Veltman, emerging young scholars, demonstrated convincingly that 
there were significant added strands of expression, both in terms of rhythm and of pitch, alongside the familiar editorial simplifications.

The practical sessions on interpretation frequently referred to the by now familiar neumes of the Graduale Triplex, but what was particularly interesting to me was the variety of interpretive approaches that were represented. Martin Quesnel provided a systematic approach to the application of the rhythmic indications to performance. Pascale Duhamel demonstrated her "High-Impact" approach, which introduces a heightened degree of rhythmic contrast. Juan Carlos Asensio Palacios, while responding to the neumes, insisted on text-declamation as the foundation of correct interpretation.

Joseph Dyer's presentation, "Observations on the Origins of the Antiphonale Missarum," compared the transmission histories of the Gregorian Sacramentary and Antiphonale, postulating a convincing case for an earlier, preCarolingian compilation of the graduale.

Jean-Pierre Noiseux's presentation illustrated stylistic differences in chant traditions through practical examples.

These are but a selection from the many fine papers presented.

Daily offices of Lauds, Vespers, and Compline, as well as Sunday Mass provided ample opportunity to experience Western chant traditions in their liturgical context.

Our aims in holding this conference were to bring together the often separate realms of scholarship and practice, to bring together anglophones and francophones, to assemble a wide demographic range of devotees from the undergraduate to the retiree, and to situate Canadian chant activity within the international context. To judge from the response to the sessions, the interaction at the banquet, and the many new connections and friendships formed, all these aims were achieved!

For information about the Gregorian Institute of Canada please visit $<w w w$. gregorian.ca>. 